OPEN ACCESS

Edited by:

João O. Malva,

University of Coimbra, Portugal

Reviewed by:

Stefano Farioli Vecchioli, Consiglio Nazionale delle Ricerche,

Gerd Kempermar German Center for Neurodegenerative Disease (DZNE) Dresden, Germany

*Correspondence: José L. Trejo jltrejo@cajal.csic.es

Specialty section: This article was submitted to Neurogenesis,

a section of the journal Frontiers in Neuroscience

Received: 16 December 2015 Accepted: 23 February 2016 Published: 14 March 2016

Citation: Gradari S, Pallé A, McGreevy KR, Fontán-Lozano Á and Trejo JL (2016)

Can Exercise Make You Smarter, Happier, and Have More Neurons? A

Hormetic Perspective.

Front. Neurosci. 10:93.

doi: 10.3389/fnins.2016.00093

\section{Can Exercise Make You Smarter, Happier, and Have More Neurons? A Hormetic Perspective}

\author{
Simona Gradari, Anna Pallé, Kerry R. McGreevy, Ángela Fontán-Lozano and José L. Trejo * \\ Laboratory of Adult Neurogenesis, Department of Molecular, Cellular and Developmental Neurobiology, Cajal Institute, \\ Consejo Superior de Investigaciones Cientificas, Madrid, Spain
}

Exercise can make you smarter, happier and have more neurons depending on the dose (intensity) of the training program. It is well recognized that exercise protocols induce both positive and negative effects depending on the intensity of the exercise, among other key factors, a process described as a hormetic-like biphasic dose-response. However, no evidences have been reported till very recently about the biphasic response of some of the potential mediators of the exercise-induced actions. This hypothesis and theory will focus on the adult hippocampal neurogenesis (AHN) as a putative physical substrate for hormesis responses to exercise in the context of exercise-induced actions on cognition and mood, and on the molecular pathways which might potentially be mediating these actions.

Keywords: exercise, adult hippocampal neurogenesis, biphasic dose-response, hormesis, molecular mechanisms, cognition, mood

\section{INTRODUCTION}

Physical activity induces pleiotropic effects for the whole organism including brain (Dishman et al., 2006). The effects of physical exercise can be described by means of a hormetic (biphasic) doseresponse curve both on cognition and mood (Mattson, 2012a), and many of these effects have been closely related to the adult hippocampal neurogenesis (AHN) in the last decade (Kempermann, 2011). AHN is a phenomenon consisting of the formation of new neurons during adult life, and certainly these new neurons are highly responsive to exercise. AHN has also been related, independently of their response to exercise, to some hippocampus-dependent behaviors and mood (Kempermann, 2011).

Taking this knowledge into consideration, we have reviewed first the literature related to the hormetic profile effects of both the exercise and its molecular mediators on the brain. Following these evidences, we have posed and discussed the hypothesis whether AHN responses display a biphasic/hormetic dose-response to exercise and whether some putative mechanisms underlying this response profile may be detected in the literature.

The answer to this question is relevant for our knowledge about the neurobiology of exercise, but nevertheless, also to raise a property of AHN (hormesis), that can easily influence and improve our attempts to manipulate adult neurogenesis beyond exercise (drugs or other interventions). 


\section{EXERCISE AND BRAIN}

Physical activity is an essential component of everyday life. Searching for food or sexual partners, chasing preys or running away from predators, seasonal migrations, and almost any regular activity related to maintaining life is usually mediated by some kind of physical activity. These life-sustaining activities involving a physical component are intimately associated to cognitive activities. The processing of information about the surrounding environment where the organism is living and moving, learning, and storing such information, and its application for decision making are cognitive processes naturally occuring at the same time the organisms are moving.

Furthermore, the relationship between physical activity and brain information processing is more relevant than a mere correlational event. The way the brain processes information changes along with the level of physical activity of the organism (Foster, 2015), but even more important, physical activity effectively changes the brain, both at a morphological and functional levels. This adaptive brain plasticity responds to the different levels of information processing demand in the way of adjusting neural resources available to process that information level (Chen and Tonegawa, 1997). These neural resources and the available changes range from neural cell metabolism and gene expression, cell and processes size, neuronal dendrite and synapse number, and blood-brain barrier properties, to synaptic plasticity. While all these changes involve existing cells, neural resources also include a form of metaplasticity (named adult neurogenesis): the capability to recruit, in some specific areas of the adult brain, more neurons which show cellular and synaptic plasticity abilities (Garcia-Segura, 2009).

In this scenario, it is not surprising that physical exercise training has been largely reported as increasing synaptic plasticity, neural cells metabolism and blood supply in an active brain area-specific way, and increasing neural processing abilities, even in humans (in adults, children, and adolescents). Besides, in human beings a specific capability for endurance running, compared to the other primates has been postulated (Mattson, 2012b). Comparisons between animal and human studies are, therefore, difficult. However, common mechanisms underlie the aspects discussed in the present work, as for example, the inflection point for the effects of different intensity levels of exercise around the anaerobic threshold (lactate threshold) used in both laboratory rodent and human studies (see below). An increasing body of literature has long demonstrated benefits of exercise for cognition in humans (reviewed by Hillman et al., 2008). In experiments with laboratory rodents, it has been long demonstrated that exercise increases cognitive performance in almost any brain area, especially at hippocampus-dependent tasks, by means of synaptic plasticity and neurogenesis increments. It increases complexity of neuronal dendrites and synapse numbers. Regular exercise induces neuroprotection in all brain areas analyzed; it improves different parameters related to neurodegenerative diseases (age of onset, progression, and severity of symptoms) both in animal models and in humans. Finally, exercise has also been reported as a useful tool to recover the symptomatology of some neurodegenerative diseases and from different brain damages and insults (Dishman et al., 2006; Mattson, 2015). From a mechanistic point of view, exercise is able to increase blood flow (Lucas et al., 2015) and oxygen consumption (Rooks et al., 2010), modulate the growth factor signaling cascade (especially IGF1 Llorens-Martin et al., 2009, BDNF Gomez-Pinilla and Hillman, 2013, and VEGF During and Cao, 2006), and increase neurotransmitter availability and function (especially dopamine, glutamate, norepinephrine, and serotonin Meeusen, 2012).

Nevertheless, exercise displays inseparable negative effects. These stressors range from thermal, metabolic, hypoxic, and oxidative, to mechanical stress (reviewed by Peake et al., 2015). These effects have been reported both in animal and human studies. The higher capacity for endurance running showed by human beings (Mattson, 2012b) would just be one stage of the hormetic response by which a low dose of a stressful stimulus activates an adaptive response that increases the resistance to a moderate-to-severe level of stress (Calabrese et al., 2007). However, a number of different approaches have demonstrated inverted-U performance curves on cognition after exercise in humans (Tomporowski, 2003). The relationship is not simple because it clearly depends on the duration of the bouts (typically intense but brief, leading to a rapid recovery of the individual's capacity) and on the individual's fitness level previous to the study, a factor under the lack of clear effects of brief bouts of intense exercise (Tomporowski, 2003), and on the motivation to participate in both acute bouts of exercise or long endurance training regimes, a factor that surely distorts any conclusion about relationships between exercise and cognitive performance in humans. On the other side, steady-state aerobic exercise causes impaired information processing and cognition depending on the level of dehydration, in turn depending on the duration of the exercise (Cian et al., 2001). As the most outstanding factor, exercise increases oxidative stress, as expected as it consists of a physical increased activity of oxygen-consuming organisms and this effect is intimately associated to variations in energy metabolism (Coyle, 2000). This aspect of exercise programs can well be underlying the negative effects of strenuous physical activity (Nieman et al., 1990; Lee et al., 1995; Andersen et al., 2013). As it is well-known that exercise displays this kind of hormetic-like non-monotonic response curve for most outcomes analyzed (Radak et al., 2005), it is relevant to take into account that this biphasic response strongly depends on oxidative stress, oxygen consumption and mitochondrial metabolism. All these evidences are related to the effects on the whole body, mainly muscle and cardiovascular systems. As for the brain, it is important to take into account that exercise induces increased generation of ROS but also antioxidant enzymes and redox signaling in the body (Powers and Jackson, 2008; Radak et al., 2013), and oxidative stress can be induced into the brain by circulating factors (Calabrese et al., 2010). As general positive effects of exercise on brain's oxidative stress has long been recognized due to an increased activity of antioxidant enzymes (reviewed by Radak et al., 2014), it has been suggested that a complex regulation and balance between exercise-induced generation of sistemic ROS-related factors and brain antioxidant enzymes are mediating the effects of exercise on the brain in 
a hormetic, bell-shaped curve, where high levels of ROS cause oxidative damage, while moderate amounts would induce an adaptive response to oxidative challenge (Radak et al., 2014).

Moreover intense, above lactate threshold level exercise induces brain mitochondrial dysfunction and decreased BDNF levels in mice (Aguiar et al., 2008), increased activity of hypothalamic paraventricular nucleus and concomitant increase in CRH expression (Timofeeva et al., 2003), suggesting a direct activation of stress responses, while others have found only positive effects of intense exercise in aged mice (Lezi et al., 2014).

A word of caution is worth to be taking into account at this time. For the present work, we have considered that the broad range of parameters related to exercise are the same for humans, rats and mice, although subtle differences exist, not only between species, but also between mouse strains, gender and even interindividual variability. Therefore, aerobic capacity, lactate and anaerobic thresholds and critical speed show similar features and the same curve profiles for human, rats and mice (Billat et al., 2005), as well as similar characteristics of maximal lactate steady state (MLSS; Ferreira et al., 2007), although noticeable differences do exist, such as a different sensitivity of MLSS for mice to endurance training compared to humans and rats (Beneke et al., 2000; Gobatto et al., 2001; Ferreira et al., 2007). All these works point to a very similar physiology of exercise and relevant parameters in laboratory rodents and humans, making the conclusions of this work relevant not only to know the specific features of rodent physiology but also to use animal models to study preclinical interventions. The most relevant distinction might be the subtle differences in the profile of aerobic-anaerobic transition between mice and both rats and humans. These differences are not critical for the topics discussed in the present work.

In this work, hormesis is considered the dual response of an individual's behavior, an organ or a cell's physiology or any other analyzed parameter in response to the graded intensity of a specific treatment/intervention (Mattson, 2008). In its most usual form, hormesis represents a dose-response curve with a biphasic profile: beneficial effects at a low dose/intensity and detrimental (inverted-J curve) or no effects (inverted-U curve) at a higher dose/intensity. Therefore, hormesis refers not only to negative effects at high doses, but also to a lack of moderate doseinduced positive effects at higher doses. As for exercise, hormesis adopts the features of pre-conditioning/adaptation to a mild, intermittent stress when coping with further higher stressors. This way, the hormesis curve is an adequate description of the effects of exercise (Radak et al., 2008). Therefore, it is relevant to consider the hormetic responses to physical exercise, focused on brain effects.

\section{BIPHASIC RESPONSES TO EXERCISE ON COGNITION AND MOOD}

It is not the aim of the present work to determine which are the specific characteristics that are optimal to obtain beneficial or detrimental effects with an exercise training protocol, both because the comparison between different works have been demonstrated very difficult in a number of meta-analysis, due to the inability to equate exercise intensity levels between studies, and because it is known only scarcely the many different parameters of the exercise regime influencing the exercise outcomes. What is most relevant for this work is whether authors have found biphasic responses independently of the applied protocol. Anyway, examples of reports with some of the most representative forced exercise protocols in animal studies and its both positive and negative effects on stress biomarkers, neuroplasticity and behavior are included in Table 1. Protocols vary especially when forced exercise is considered, because voluntary running protocols use to depend largely on the animals' motivation to run.

Physical exercise in human beings presents a biphasic dose-response curve for a huge number of cognition/mood parameters, depending on the intensity level of exercise program. Specifically, inverted U-shaped curves are found with an inflection point around the lactate or ventilatory thresholds. In a recent meta-analysis (Oliveira et al., 2015) on Feeling Scale (Hardy and Rejeski, 1989), it has been demonstrated that the intensity of the exercise is the main determinant to establish affective responses (no matter whether the exercise is self-selected or imposed). Beneficial effects of exercise in humans have been largely reported in a dose-response way (see Gomez-Pinilla and Hillman, 2013 for a recent review and Cotman and Berchtold, 2002; Dishman et al., 2006; Ang and Gomez-Pinilla, 2007; Mattson, 2012a,b). In a similar way, the subjective perception of the performance is decreased after an intense exercise (Grebot et al., 2003), and the stress associated to high intensity exercise has been reported to impair working and declarative memory (Taverniers et al., 2010).

In laboratory rodents, it is very well-known the high number of beneficial effects that a moderate exercise program can induce (Cotman and Berchtold, 2002; Kramer et al., 2006; Cotman et al., 2007). These beneficial effects include a variety of different tasks ranging from water maze (Ding et al., 2006), passive avoidance (Samorajski et al., 1985; Radak et al., 2006), contextual fear conditioning (Baruch et al., 2004; Burghardt et al., 2006) to radial arm maze (Schweitzer et al., 2006). On the contrary, it has been reported that high intensity exercise induces a variety of detrimental effects, including brain region-specific (amygdala - dorsal striatum becoming affected while hippocampus seem to be unaffected) and taskspecific (differences found in some associative learning taskstone/shock conditioning-but not others-fear conditioning-and not in spatial reference and working memory tasks-water maze-) impairments in memory processing (Aguiar et al., 2010). Similar results have been found for passive avoidance tasks and contextual fear conditioning closely associated to brain oxidative stress (Rosa et al., 2007). Other authors have reported impairment of spatial-water maze-learning after high intensity exercise by using a different ergometer (treadmill running), although only at early acquisition phase (Blustein et al., 2006). High intensity levels of exercise can promote no improvements at all on cognition even after voluntary running and selective breeding for high levels of voluntary exercise (Rhodes et al., 2003). The deleterious effects of high intensity exercise can 
TABLE 1 | Examples of positive, lack of positive, and negative effects of different forced training intensities on stress, behavior, and neurogenesis.

\begin{tabular}{|c|c|c|c|c|c|}
\hline Animal model & Treadmill protocol & Stress biomarkers & Effects on cognition & $\begin{array}{l}\text { Histological and } \\
\text { molecular procedures }\end{array}$ & References \\
\hline $\begin{array}{l}\text { Brain ischemia rat } \\
\text { model: Adult } \\
\text { Sprague-Dawley (SD) } \\
\text { rats }\end{array}$ & $\begin{array}{l}\text { - Sedentary (SED) group: } 0 \\
\text { m/min } \\
\text { - Low-intensity exercise (LI) } \\
\text { group: } 8 \text { m/min } \\
\text { - High-intensity exercise (HI) } \\
\text { group: } 20 \mathrm{~m} / \mathrm{min} \\
\text { Duration in each group: } \\
30 \mathrm{~min} / \text { day for } 14 \text { days. }\end{array}$ & $\begin{array}{l}\text { Serum corticosterone } \\
\text { (CORT) } \\
\text { Only HI group presented } \\
\text { higher serum CORT } \\
\text { concentration (levels around } \\
200 \mu \mathrm{g} / \mathrm{ml} \text { ) than SED group. }\end{array}$ & $\begin{array}{l}\text { Morris Water Maze (MWM) task } \\
\text { LI but not HI group } \\
\text { demonstrated a better spatial } \\
\text { memory performance than } \\
\text { SED group by spending more } \\
\text { time in the target (platform) } \\
\text { quadrant. }\end{array}$ & $\begin{array}{l}\text { BDNF, Synapsin-I, PSD-95 } \\
\text { Only the LI but not HI group } \\
\text { presented increased levels } \\
\text { of BDNF, Synapsin-I and } \\
\text { PSD-95 in the contralesional } \\
\text { hippocampus compared to } \\
\text { the SED group. }\end{array}$ & Shih et al., 2013 \\
\hline $\begin{array}{l}\text { Adult male } \\
\text { Sprague-Dawley (SD) } \\
\text { with severe cortical } \\
\text { impact }\end{array}$ & $\begin{array}{l}\text { - Sedentary (Control) group: } \\
0 \text { m/min } \\
\text { - Low-intensity (LI) group: } \\
\text { Progressive speed until } \\
\text { reaching a maximum of } 8 \\
\mathrm{~m} / \text { min from day } 8 \text { to day } \\
14 \text { (end of the protocol). } \\
\text { - High-intensity (HI) group: } \\
\text { Progressive speed until } \\
\text { reaching } 12 \mathrm{~m} / \mathrm{min} \text { from } \\
\text { day } 4 \text { to the end of the } \\
\text { running protocol. } \\
\text { Duration: } 30 \mathrm{~min} / \text { day for } \\
14 \text { days. }\end{array}$ & $\begin{array}{l}\text { No stress biomarkers were } \\
\text { assessed }\end{array}$ & $\begin{array}{l}\text { MWM task } \\
\text { LI group had a shorter latency } \\
\text { to locate the platform and a } \\
\text { better performance in spatial } \\
\text { memory compared to the } \\
\text { control group. } \\
\text { The HI exercise group showed } \\
\text { a longer latency and a mild } \\
\text { improvement in spatial memory } \\
\text { compared to the control group. }\end{array}$ & $\begin{array}{l}\text { BDNF } \\
\text { LI group had increased } \\
\text { levels of BDNF in the } \\
\text { contralateral hippocampus } \\
\text { respect de control group. } \\
\text { p-CREB } \\
\text { LI group had increased } \\
\text { levels of p-CREB in the } \\
\text { contralateral hippocampus } \\
\text { respect de control group. }\end{array}$ & Shen et al., 2013 \\
\hline Adult rats & $\begin{array}{l}\text { Treadmill with speed } \\
\text { paradigm based on the } \\
\text { lactate threshold (LT being } \\
\text { around } 20 \mathrm{~m} / \mathrm{min}) \\
\text { - Sedentary control (CONT) } \\
\text { group: Duration: } 6 \text { weeks } \\
\text { - Stress free mild exercise } \\
\text { (ME, <LT) group: } \\
\text { Duration: } 6 \text { weeks. } \\
\text { - Intense exercise (IE, >LT) } \\
\text { group: Duration: } 6 \text { weeks. }\end{array}$ & $\begin{array}{l}\text { Only IE causes general } \\
\text { adaptive syndrome (GAS): } \\
\text { hypercorticosteronemia, } \\
\text { adrenal hypertrophy, thymic } \\
\text { atrophy. }\end{array}$ & $\begin{array}{l}\text { MWM task } \\
\text { ME led to enhanced memory, } \\
\text { but not learning, compared } \\
\text { with CONT. } \\
\text { IE produced no changes in } \\
\text { either learning capacities, } \\
\text { probably due to GAS. }\end{array}$ & $\begin{array}{l}\text { Adult Hippocampal } \\
\text { Neurogenesis (AHN) } \\
2 \text { weeks of training with } \\
\text { stress-free mild exercise } \\
\text { (ME), but not intense } \\
\text { exercise (IE), comprising } \\
\text { exercise stress, promotes } \\
\text { adult hippocampal } \\
\text { neurogenesis. }\end{array}$ & $\begin{array}{l}\text { Inoue et al., } \\
2015 a\end{array}$ \\
\hline $\begin{array}{l}\text { Male albino } \\
\text { Sprague-Dawley rats } \\
\text { (4-6 weeks old) }\end{array}$ & $\begin{array}{l}\text { For } 4 \text { weeks: } \\
\text { intensity of } 70 \% \text { of } \\
\text { maximal oxygen } \\
\text { consumption, for } 1 \mathrm{~h} / \text { day, } \\
5 \text { day/week. }\end{array}$ & $\begin{array}{l}\text { No stress biomarkers were } \\
\text { assessed }\end{array}$ & $\begin{array}{l}\text { One-trial step-through passive } \\
\text { avoidance test: } \\
\uparrow \text { learning and memory. }\end{array}$ & $\begin{array}{l}\text { No histological or molecular } \\
\text { procedures were performed }\end{array}$ & Chen et al., 2008 \\
\hline Adult Wistar Rats & $\begin{array}{l}\text { Treadmill with speed } \\
\text { paradigm based on the } \\
\text { lactate threshold } \\
\text { - Sedentary control (CONT) } \\
\text { group: } 0 \mathrm{~m} / \mathrm{min}\end{array}$ & $\begin{array}{l}\text { Plasma CORT } \\
\text { Only IE had the higher } \\
\text { CORT concentration than } \\
\text { CONT group. }\end{array}$ & $\begin{array}{l}\text { No behavioral tasks were } \\
\text { performed }\end{array}$ & $\begin{array}{l}\text { AHN } \\
\text { ME was better suited to } \\
\text { improve AHN, especially in } \\
\text { regards to the survival and } \\
\text { maturation of newborn } \\
\text { neurons. }\end{array}$ & $\begin{array}{l}\text { Inoue et al., } \\
2015 a\end{array}$ \\
\hline
\end{tabular}


TABLE 1 | Continued

Animal model
Mild-exercise (ME, <LT)
group: $15 \mathrm{~m} / \mathrm{min}$,
$60 \mathrm{~min} /$ day.
Intense-exercise (IE,
>LT) group: $40 \mathrm{~m} / \mathrm{min}$,
$60 \mathrm{~min} /$ day.
Duration: 6 weeks in
total including the
habituation period.
Running took place
during the dark phase
(19:00 and 22:00).

- Mild-exercise (ME, <LT) group: $15 \mathrm{~m} / \mathrm{min}$, $60 \mathrm{~min} /$ day

- Intense-exercise (IE, >LT) group: $40 \mathrm{~m} / \mathrm{min}$ min/day. total including the habituation period. during the dark phas (19:00 and 22:00).

Sprague-Dawley rats (5-weeks-old)
Treadmill: initial speed of 9 $\mathrm{m} / \mathrm{min}$ for 20-60 min per day, 5 days per week for the first week, followed by $60 \mathrm{~min} /$ day at the same speed, 5 days/week. Increasing speed about 3 $\mathrm{m} / \mathrm{min}$ per week reaching $16 \mathrm{~m} / \mathrm{min}$ at the end of the training period. Running Wheel: singly placed in cages.

\section{Male juvenile} Sprague-Dawley rats (5 weeks old)

\section{For 1 week:}

$30 \mathrm{~min} /$ day.
Three groups:

- low intensity (LI) group: ran at $5 \mathrm{~m} / \mathrm{min}$ for the first $5 \mathrm{~min}, 8 \mathrm{~m} / \mathrm{min}$ for the next $5 \mathrm{~min}$ and $11 \mathrm{~m} / \mathrm{min}$ for the remaining $20 \mathrm{~min}$; - moderate intensity (MI) group ran at $8 \mathrm{~m} / \mathrm{min}$ for the first $5 \mathrm{~min}, 11 \mathrm{~m} / \mathrm{min}$ for the next $5 \mathrm{~min}$ and 14 $\mathrm{m} / \mathrm{min}$ for the remaining 20 min;

- high intensity $(\mathrm{HI})$ group ran at $8 \mathrm{~m} / \mathrm{min}$ for the first $5 \mathrm{~min}, 11 \mathrm{~m} / \mathrm{min}$ for the next $5 \mathrm{~min}$ and $22 \mathrm{~m} / \mathrm{min}$ for the remaining $20 \mathrm{~min}$.

Male Sprague-Dawley rats (2 weeks of age): induction of autism-like with valproic acid injections.
No stress biomarkers were assessed

No stress biomarkers were assessed

DNA microarray

- ME-influenced genes were principally related to lipid metabolism, protein synthesis and inflammatory response, which are recognized as associated with AHN

- IE-influenced genes linked to an excessive inflammatory immune response, known to be negative regulator of hippocampal neuroadaptation, were identified.

\section{Fear conditioning:}

No changes in the acquisition

of fear-evoked conditional

responses and

$\uparrow$ context-conditioned freezing

responses in treadmill and

running wheel.

Only treadmill improved the

cue-conditioned performance.
No histological or molecular Lin et al., 2012 procedures were performed 
TABLE 1 | Continued

\begin{tabular}{|c|c|c|c|c|c|}
\hline Animal model & Treadmill protocol & Stress biomarkers & Effects on cognition & $\begin{array}{l}\text { Histological and } \\
\text { molecular procedures }\end{array}$ & References \\
\hline C57BL/J6 mice & $\begin{array}{l}\text { - Controls (CON): } 0 \mathrm{~m} / \mathrm{min} \\
\text { - Regular Runners (RR): } 10 \\
\text { m/min, at the same time } \\
\text { of the day until } 28 \text { days } \\
\text { - Irregular Duration Runners } \\
\text { (IDR): } 10 \mathrm{~m} / \mathrm{min} \text {. Same } \\
\text { time of the day but } \\
\text { variable duration. } \\
\text { - Irregular time-of-day } \\
\text { runners (ITR): } 10 \mathrm{~m} / \mathrm{min} \text {. } \\
\text { Same duration but at } \\
\text { different time of day. }\end{array}$ & $\begin{array}{l}\text { Serum CORT levels } \\
\text { Day 4: No differences were } \\
\text { found among runners. } \\
\text { Day 29: RR group had } \\
\text { significantly lower levels of } \\
\text { serum CORT } \\
\text { (110-150ng/ml at 10:00 } \\
\text { am). }\end{array}$ & $\begin{array}{l}\text { MWM task } \\
\text { The RR group had a lower } \\
\text { escape latency in the } \\
\text { acquisition compared to the } \\
\text { CON or IDR group. } \\
\text { Regarding memory } \\
\text { consolidation, RR spent more } \\
\text { time in the target quadrant } \\
\text { compared to the other three } \\
\text { groups. }\end{array}$ & $\begin{array}{l}\text { RR group presented higher } \\
\text { levels of } \mathrm{BrdU}^{+} \text {cells } \\
\text { compared to the other } \\
\text { groups. }\end{array}$ & Li et al., 2013 \\
\hline C57BL/J6 mice & $\begin{array}{l}\text { Forced Walking Wheel } \\
\text { System } \\
\text { - Sedentary: Om/min } \\
\text { - Low impact runners (LIR): } \\
10 \mathrm{~m} / \mathrm{min} .45 \mathrm{~min} / \text { day. } \\
\text { Duration: } 10 \text { weeks. } \\
\text { - High impact runners (HIR): } \\
21 \mathrm{~m} / \mathrm{min}, 45 \mathrm{~min} / \text { day. } \\
\text { Duration: } 5 \text { weeks. }\end{array}$ & $\begin{array}{l}\text { No stress biomarkers were } \\
\text { assessed }\end{array}$ & $\begin{array}{l}\text { MWM task } \\
\text { In the acquisition phase, HIR } \\
\text { had longer escape latencies } \\
\text { compared to LIR group and } \\
\text { sedentary controls. } \\
\text { Regarding memory } \\
\text { consolidation performance, LIR } \\
\text { crossed the platform quadrant } \\
\text { more than HIR. } \\
\text { Rotorod test } \\
5 \text { weeks of HIR led to } \\
\text { significant improvement in } \\
\text { rotorod test performance. }\end{array}$ & $\begin{array}{l}\text { No histological or molecular } \\
\text { procedures were performed }\end{array}$ & $\begin{array}{l}\text { Kennard and } \\
\text { Woodruff-Pak, } \\
2012\end{array}$ \\
\hline $\begin{array}{l}\text { Adult male C57BL/6 } \\
\text { mice }\end{array}$ & $\begin{array}{l}\text { For } 2 \text { weeks: } \\
7 \text { days } / \text { week, } 40 \mathrm{~min} / \text { day, } \\
\text { speed } 12 \mathrm{~m} / \mathrm{min} \text {. }\end{array}$ & $\begin{array}{l}\text { No stress biomarkers were } \\
\text { assessed }\end{array}$ & No behavioral tasks perfomed & $\begin{array}{l}\text { AHN } \\
\uparrow \text { number of BrdU+ cell; } \\
\uparrow \text { density of spine of granule } \\
\text { cells in the DG }\end{array}$ & $\begin{array}{l}\text { Glasper et al., } \\
2010\end{array}$ \\
\hline $\begin{array}{l}\text { Adult male C57BL/6J } \\
\text { mice (5-weeks-old) }\end{array}$ & $\begin{array}{l}10 \mathrm{~m} / \mathrm{min}, 20 \mathrm{~min} \text { for the } \\
\text { first day, with an } \\
\text { increment of } 10 \mathrm{~min} / \text { day } \\
\text { until reaching } 60 \mathrm{~min} / \text { day } \\
\text { to fulfill the } 70 \% \text { of } \\
\text { maximal oxygen } \\
\text { consumption. The running } \\
\text { duration was } 60 \mathrm{~min} / \text { day, } \\
\text { and the running speed } \\
\text { was increased gradually } \\
\text { from } 10 \text { to } 12 \mathrm{~m} / \mathrm{min} \text {. The } \\
\text { speed was accelerated } 1 \\
\mathrm{~m} / \mathrm{min} \text { every } 2 \text { weeks. }\end{array}$ & $\begin{array}{l}\text { No stress biomarkers were } \\
\text { assessed }\end{array}$ & No behavioral tasks perfomed & $\begin{array}{l}\text { AHN } \\
\uparrow \text { number of Nestin }{ }^{+} \text {cells in } \\
\text { the SGZ; } \\
\uparrow \text { number of Ki67 } 7^{+} \text {cells; } \\
\uparrow \text { more } \mathrm{DCX}{ }^{+} \text {cells, with } \\
\text { prominently developed } \\
\text { dendrites; } \\
\uparrow \text { pCREB expression; } \\
\uparrow \mathrm{BDNF} \text { expression }\end{array}$ & Nam et al., 2014 \\
\hline $\begin{array}{l}\text { Male BALB/c mice } \\
\text { (3-months old) }\end{array}$ & $\begin{array}{l}\text { For } 4 \text { weeks: } \\
10 \mathrm{~m} / \mathrm{min} \text {, for } \\
20-60 \mathrm{~min} / \text { day, } 5 \\
\text { days/week. }\end{array}$ & $\begin{array}{l}\text { No stress biomarkers were } \\
\text { assessed }\end{array}$ & $\begin{array}{l}\text { One-trial passive avoidance: } \\
\uparrow \text { retention latency. } \\
\text { Multiple-trial passive } \\
\text { avoidance: }\end{array}$ & $\begin{array}{l}\text { No histological or molecular } \\
\text { procedures were performed }\end{array}$ & Liu et al., 2008 \\
\hline
\end{tabular}


TABLE 1 | Continued

\begin{tabular}{|c|c|c|c|c|c|}
\hline Animal model & Treadmill protocol & Stress biomarkers & Effects on cognition & $\begin{array}{l}\text { Histological and } \\
\text { molecular procedures }\end{array}$ & References \\
\hline & & & $\begin{array}{l}\uparrow \text { just the retention phase of } \\
\text { memory (not the acquisition). }\end{array}$ & & \\
\hline $\begin{array}{l}\text { C57BL/6 male mice (19 } \\
\text { months) }\end{array}$ & $\begin{array}{l}\text { For } 8 \text { weeks, } 5 \\
\text { days/week, } 2 \\
\text { sessions/day, } 5^{\circ} \text { incline. } \\
\text { For the first week, each } \\
\text { session consisted of a } \\
\text { 10-min warm-up at } 15 \\
\mathrm{~m} / \mathrm{min} \text { followed by } 30 \text { min } \\
\text { at } 18 \mathrm{~m} / \mathrm{min} \text {. } \\
\text { During the following } 7 \\
\text { weeks, treadmill speed } \\
\text { was progressively } \\
\text { increased every week. } \\
\text { Specifically, for weeks } 2 \text {, } \\
3,4,5,6,7 \text {, and } 8 \text { the } \\
\text { treadmill speed was set to } \\
21 \mathrm{~m} / \mathrm{min}, 22 \mathrm{~m} / \mathrm{min}, 23 \\
\mathrm{~m} / \mathrm{min}, 24 \mathrm{~m} / \mathrm{min}, 25 \\
\mathrm{~m} / \mathrm{min}, 25 \mathrm{~m} / \mathrm{min} \text {, and } 26 \\
\mathrm{~m} / \mathrm{min}, \text { respectively. }\end{array}$ & $\begin{array}{l}\text { No stress biomarkers were } \\
\text { assessed }\end{array}$ & No behavioral tasks perfomed & $\begin{array}{l}\text { No changes in DCX mRNA } \\
\text { levels; } \\
\uparrow \text { VEGF mRNA; } \\
\text { No changes in BDNF mRNA } \\
\text { levels }\end{array}$ & Lezi et al., 2014 \\
\hline
\end{tabular}

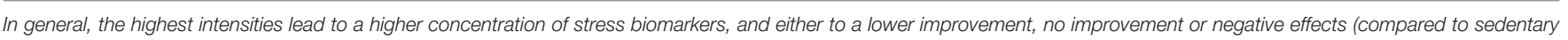

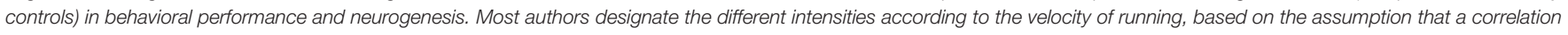

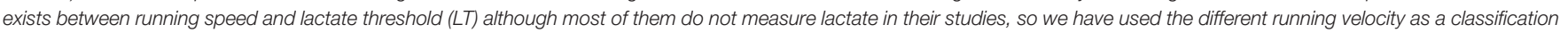

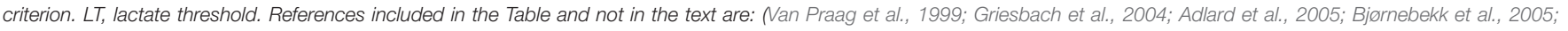

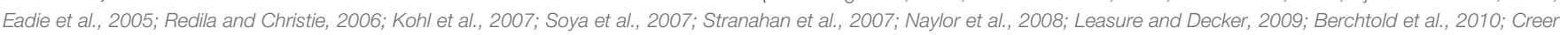

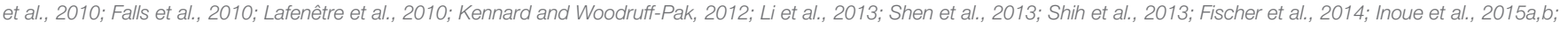
Radahmadi et al., 2015).

also rely on individual variability, depending on the basal performance level previous to training (Braszko et al., 2001).

To our knowledge, very few studies have reported beneficial effects of high intensity exercise on cognition. It is noteworthy to mention one work reporting an improved memory performance in both strenuous and over-training exercise programs in a passive avoidance test (Ogonovszky et al., 2005). Surprisingly, this work found an increase in the BDNF levels only in the group performing most intense exercise.

As for the biphasic dose-response to exercise in animal studies, a recent work has reported evidences of biphasic dose-response curves for exercise effects on cognition in laboratory mice. Memory retention in an object recognition task was significantly improved at low-moderate intensity exercise while high and very-high intensity exercise induced no and negative effects, respectively, on discrimination (García-Capdevila et al., 2009).

The features of inverted- $U$ shaped dose-response curves (the maximum-hormetic-response, the width of hormetic zone, the No Observed (Adverse) Effect Level (NOAEL), the distance to NOAEL and the zero equivalent point (Calabrese, 2008) to exercise are quite relevant considering that they strongly depend on the animal's previous health, brain specific outcomes analyzed, and parameters of exercise programs including whether the exercise is voluntary or forced (Radák et al., 2001, and see below).

A very relevant aspect of the hormetic response to exercise is the biological meaning. As already stated, sedentary life has well-known detrimental effects on brain functioning, while exercise is one of the most outstanding conducts in order to maintain health as well as a healthy aging, both in animal and humans. It is plausible to postulate that exercise effects are increasingly positive within the range from sedentary life to moderate and high intensity exercise. This response to exercise would show a sigmoidal profile, due to a ceiling effect: beyond a given level of exercise intensity, training time, or frequency of training, no further positive effects would accumulate due to a maximum plastic capacity of our body and brain to change in response to activity and/or to a maximum ability to modify the body and brain's performance. The evidences reviewed above suggest that this is not the case. The response to exercise seems to fit better with a hormetic profile where increasing intensity, training time, or frequency of training cause the disappearance of the positive effects of low-to-moderate exercise. Why might this be so? As exposed above, exercise is a stress. The adaptive effects of exercise on both muscles, bones, immune system, cardiovascular system, and brain make the whole body healthier and resistant to further stress. But nevertheless, there is a threshold of intensity from where the exercise-induced stress leads to non-positive, even in some cases detrimental effects (an inverted- $U$ or even an invertedJ hormetic curve) due to the canonical long-term actions of stress hormones in the whole body. Therefore, the inherent stress associated to physical exercise might be postulated under the hormetic profile of responses to exercise. Anyway, it will be below presented a second putative explanation for the biological 
evolutionary meaning of hormetic responses to exercise focused on AHN.

\section{MOLECULAR MEDIATORS OF EXERCISE ACTIONS}

A long list has been accounted with the factors responsible for the different effects of exercise on brain, both positive and negative. Among those most relevant, an activity-driven growth factors cascade including IGF1, BDNF, and VEGF (Cotman et al., 2007; Llorens-Martin et al., 2008; Pérez-Domper et al., 2013; Szuhany et al., 2015) has been postulated as responsible for most of the beneficial effects together with the anti-inflammatory actions (Silverman and Deuster, 2014), while the oxidative stress signaling has been pointed out as the most outstanding detrimental factor after exercise. Other factors with a clear, direct influence on the outcomes of exercise training protocols are diet and lifestyle (Gomez-Pinilla, 2008). It is far beyond the scope of this review to mention an extensive list of molecular mediators of exercise actions. A well-known consensus (Mattson et al., 2004) establishes physical-cognitive activity and dietary restriction as inducing a mild, metabolic stress on neural cells (through increased levels of intracellular calcium and reactive oxygen species). This pathway activates several transcription factors like CREB and NF-kB, controlling BDNF and antiapoptotic gene (such as $\mathrm{Bcl}-2$ ) expression. These factors drive cell survival, synaptic plasticity and neurogenesis processes.

In the present work, we aim to emphasize the increasing body of evidences showing that both positive and negative effects of exercise have usually been found mediated by the same factors in a hormetic-like biphasic dose-response. To cite just a few examples, many of the positive effects of exercise depend on the concomitant increases of BDNF (Marosi and Mattson, 2014) and IGF1 levels (Llorens-Martin et al., 2009), as well as calorie restriction interacts with the individual's activity level (Mattson, 2000; Dietrich and Horvath, 2012), while high levels of BDNF and IGF1 may induce negative effects on the brain (Gwag et al., 1995; Ramsden et al., 2003) and the energy intake is associated to the risk of developing neurodegenerative diseases in a biphasic dose-response. Furthermore, it is not casual that all these factors and lifestyles are directly related to energy balance.

While all the above-mentioned factors are directly involved in the effects of physical training on cognition and mood, in the last decade a growing literature has accumulated pointing to the adult neurogenesis to be closely related to these changes and under the direct action of those growth factors.

\section{EXERCISE ACTIONS AND ADULT HIPPOCAMPAL NEUROGENESIS}

Adult neurogenesis is the production of new functional neurons in the adult brain (Kempermann, 2011). It is well recognized that physical activity influences the level of adult neurogenesis in hippocampus as well as learning recruits newborn neurons in both hippocampus and olfactory system, and environmental enrichment increase immature neurons survival (see classical reviews by Kempermann et al., 1999; Mattson, 2000; Olson et al., 2006, and an extensive, recent review in Kempermann, 2011). Some evidence also suggests a potential effect of exercise on the olfactory system (Chae et al., 2014) although conflicting evidence has also been reported (Brown et al., 2003). This kind of experience-driven plasticity has even been proposed as a necessary process to the fine tuning of brain functioning (Opendak and Gould, 2015). A number of different mechanisms has been demonstrated in close relationship to this exercise actions on adult neurogenesis, the most outstanding being IGF1 (Trejo et al., 2001, 2008; Llorens-Martin et al., 2009; LLorensMartín et al., 2010; Glasper et al., 2010), BDNF (Bekinschtein et al., 2011; Rothman and Mattson, 2013; Vivar et al., 2013), VEGF (Fabel et al., 2003; During and Cao, 2006), and Wnt pathway (Chen and Do, 2012; Bayod et al., 2014), to cite just a few. Examples of reports with some of the most representative exercise protocols and its effects on cognition and AHN are included for both forced (in Table 1) and voluntary exercise (in Table 2).

\section{BIPHASIC RESPONSES OF ADULT HIPPOCAMPAL NEUROGENESIS}

AHN has been reported displaying hormetic-like non-monotonic response curves after several treatments/interventions. One example of this biphasic response is driven by adrenal steroids, in turn one of the best known cases of biphasic responses in the brain (Joëls, 2006). A dual population of receptors mediates the mechanism with different affinities for the substrate and very different actions. At low concentrations, glucocorticoids induce supportive and survival actions on dentate granule neurons of the hippocampus by mean of the mineralocorticoid receptor, while at higher concentrations, a deleterious effect is achieved through the glucocorticoid receptor (Sapolsky et al., 1986; McEwen, 2012). A similar scenario takes place when considering the role of glucocorticoids and adult neurogenesis (Schoenfeld and Gould, 2013). While low levels of glucocorticoid receptor (GR) activation is maintained (as for example while living in an impoverished environment, or with a sedentary lifestyle), low levels of adult neurogenesis are observed (both cell proliferation and maturation), while an enriched environment, regular moderate exercise, or learning, generates a normal GR activation and consequently, basal levels of adult neurogenesis. On the other end, high GR activity driven by uncontrollable stress decreases dramatically the neurogenesis by affecting both precursor proliferation and immature neuron differentiation. This scenario adopts a well-known inverted U-shaped biphasic response (Saaltink and Vreugdenhil, 2014). The mechanisms of adrenal steroids-induced inhibition of cell proliferation in the dentate gyrus (Gould and Tanapat, 1999) are mediated by N-Methyl-D-aspartate receptor (Cameron et al., 1997).

Apart from this well-known example of hormetic response, a body of evidences has accumulated in recent years with further examples. Thus, neural stem cells treated with low levels of chemical, physical or pharmacological stimuli (otherwise high concentrations being toxic) have been shown to protect 
TABLE 2 | Examples of voluntary exercise protocols (running wheel).

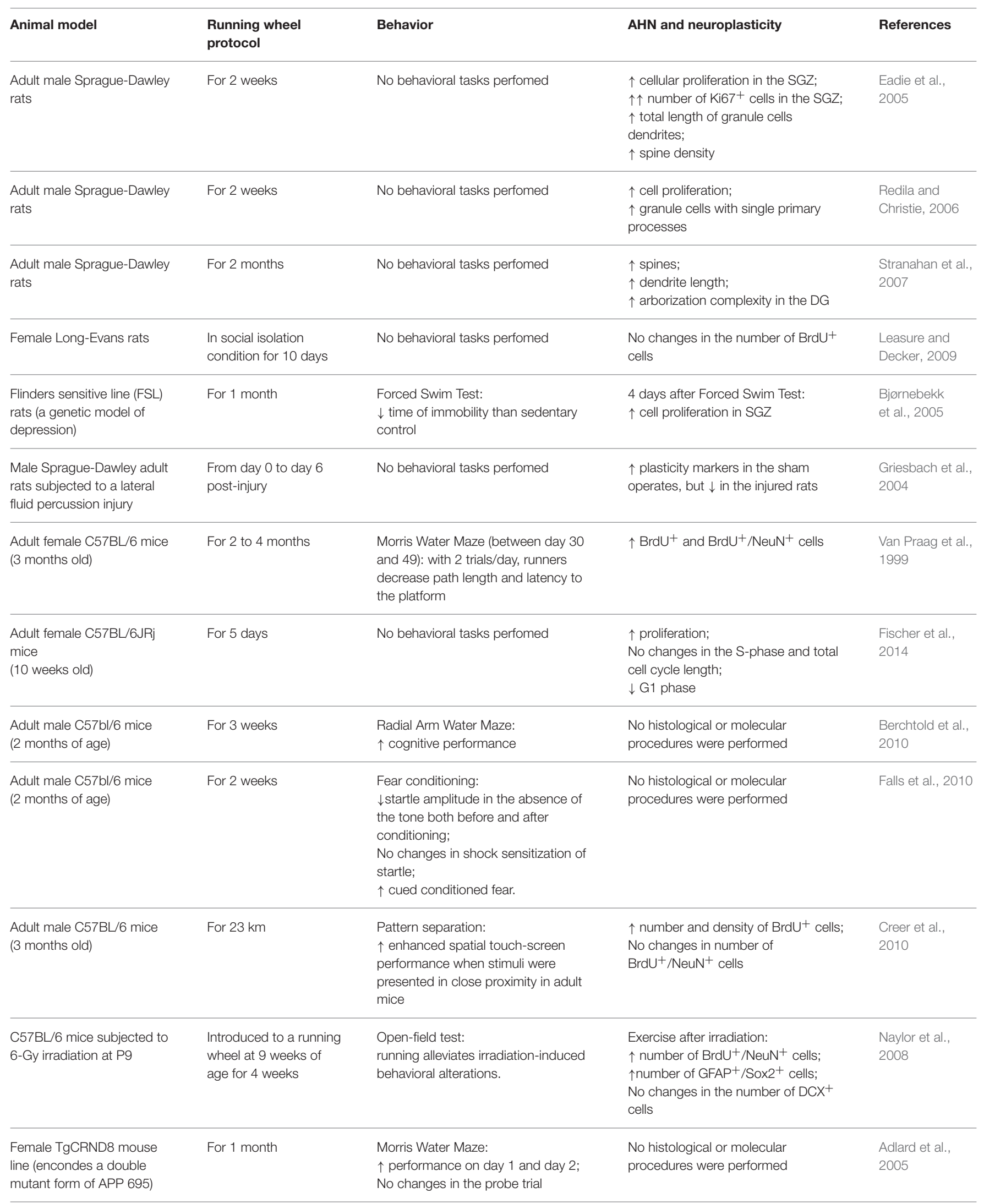


TABLE 2 | Continued

\begin{tabular}{|c|c|c|c|c|}
\hline Animal model & $\begin{array}{l}\text { Running wheel } \\
\text { protocol }\end{array}$ & Behavior & AHN and neuroplasticity & References \\
\hline $\begin{array}{l}\text { Female R6/2 mice } \\
\text { (a transgenic model of } \\
\text { Huntington's disease) }\end{array}$ & $\begin{array}{l}5 \text { mice per cage with } \\
\text { access to two running } \\
\text { wheels for } 4 \text { weeks }\end{array}$ & No behavioral tasks perfomed & $\begin{array}{l}\text { No changes in cell proliferation; } \\
\text { No changes in the number of neural } \\
\text { progenitor cells; } \\
\text { No changes in the survival of } \\
\text { newborn hippocampal neurons }\end{array}$ & Kohl et al., 2007 \\
\hline $\begin{array}{l}\text { Female synRas } \\
\text { (a mouse model with } \\
\text { reduced neurogenesis) } \\
\text { ( } 2-3 \text { months old) }\end{array}$ & For 12 days & $\begin{array}{l}\text { Novel object recognition task: } \uparrow \\
\text { performance }\end{array}$ & $\begin{array}{l}\uparrow \text { proliferation rate; } \\
\uparrow \text { density of } \mathrm{DCX}^{+} \text {cells; } \\
\uparrow \text { dendritic arborization of the } \\
\text { immature neurons }\end{array}$ & $\begin{array}{l}\text { Lafenêtre et al., } \\
2010\end{array}$ \\
\hline
\end{tabular}

Voluntary running increases hippocampal neurogenesis and improves learning. References included in the Table and not in the text are: (Llorens-Martín et al., 2006; Chen et al., 2008; Liu et al., 2008; Glasper et al., 2010; Lin et al., 2012; Lezi et al., 2014; Nam et al., 2014).

these cell precursors when the brain becomes affected by a neurodegenerative disease (reviewed in Wang, 2013). One recent work has demonstrated that the proneurogenic effect of calorie restriction is mediated by the receptor for the orexigenic hormone acyl-ghrelin and the neurogenic transcription factor Egr1 (Hornsby et al., 2016). This receptor is involved in the hormetic-like response of the adult neurogenesis to energy balance. In a similar way, the neurogenic effect of some ginsenosides has been shown with a biphasic dose- and timedependent regulation (Liu et al., 2007), a property shared by a growing number of phytochemicals (reviewed by Mattson et al., 2007). Certainly, the list of biphasic responses of AHN to different compounds is enormous, including oxytocin (Leuner et al., 2012), bisphenol (Kim et al., 2011), allopregnanolone (Wang, 2014), lead toxic exposition (White et al., 2007), statins (Chen et al., 2003), and even fluoxetin (Guilloux et al., 2013). Nevertheless, both VEGF and TGF- $\beta$ display a biphasic action on neurogenesis. High doses of VEGF downregulates endogenous VEGF receptors (increasing neuronal differentiation and decreasing progenitor proliferation). Low dose upregulates VEGF receptors (with no clear effect in proliferation or differentiation, Meng et al., 2006). Low doses of TGF- $\beta$ promote neurogenesis while high doses induce apoptosis in autonomic gangliogenesis (Hagedorn et al., 2000).

Therefore, as a body of evidences has been accumulated about biphasic responses to exercise of a variety of brain parameters including cognition and mood, and about biphasic responses of AHN to a variety of factors, and AHN has been postulated as a necessary mediator of many of the effects of exercise, the next question is whether biphasic responses of AHN exist to exercise.

\section{HYPOTHESIS AND FIRST EVIDENCES SUPPORTING A BIPHASIC RESPONSE OF ADULT HIPPOCAMPAL NEUROGENESIS TO EXERCISE}

Taking into account the above indirect evidences and two direct evidences recently reported (see below), we propose the hypothesis that adult neurogenesis might be a physical substrate for hormetic responses to exercise on cognition and mood.
This hypothesis must be tested by analyzing the response of a battery of parameters associated to the AHN to increasing levels of exercise intensities, with higher intensities being above lactate (anaerobic) threshold (Billat et al., 2005). We suggest that this hypothesis would fit to the cited literature, to the direct evidences mentioned below, and to future data testing this possibility, best than the sigmoidal dose-response reported up to date. However, the dose-response of AHN to exercise is very well-known (Holmes et al., 2004). This response was initially found to be monotonic, as raising the exercise intensity (exercise volume) from the basal level of sedentary control animals rapidly leads to increases in neurogenesis rate. Not so many evidences have been accumulated for biphasic responses when exercise intensity reaches strenuous or very high levels. In fact, to our knowledge only a few works have reported evidences in this direction. A work reports enhanced neurogenesis (BrdU/NeuN-double immunoreactivity, no stereological methods) and increases in BDNF, NMDAR1, and Flk-1 mRNA only after low intensity exercise, while high intensity exercise brought all parameters back to control, sedentary levels (Lou et al., 2008). A second group, which had previously demonstrated a ceiling effect in the exercise actions above lactate threshold (intense exercise) in spatial memory and in AHN in rats (Inoue et al., 2015a,b), have also reported recently a significant inverted U-shaped dose-response of the BrdU/DCX-positive cells in the adult dentate gyrus to increasing levels of exercise (sedentary animals, subLactate threshold, and supraLactate threshold exercise), being the number of newborn, immature neurons increased only in the subLactate threshold, mild exercise group, together with no increase in ACTH or CORT levels (Okamoto et al., 2015). Interestingly, this neurogenesispromoting effect of sub-stress threshold (mild) exercise depends on glucocorticoid receptor activation, suggesting a facilitative, permissive role of GC receptors, and moderate glucocorticoid levels during mild exercise. These evidences, together with the above mentioned hormetic-like responses to GC actions of hippocampus, make glucocorticoid receptors to be suggested a very plausible mechanism mediating the hormetic, biphasic dose-response of adult neurogenesis to the different intensity levels of exercise. But GRs might not be alone in these responses. 
Finally, other work reported that other forms of hormetic $\mathrm{U}$-shape responses of AHN to exercise exists, as a lack of significant pro-proliferative effects induced by exercise has been reported over time (Kronenberg et al., 2006). Therefore, hormetic responses to exercise of adult neurogenesis can be observed not only as a consequence of increasing doses but also after long-term trainings.

It is worth to consider what can the biological meaning of this profile response to exercise be. As discussed above in Section Biphasic Responses to Exercise on Cognition and Mood, the inherent stress associated to exercise can induce a detrimental increment in stress hormone levels, counteracting the positive actions of exercise beyond a given intensity level in the whole body including brain. The sensitivity to these hormones can even be more relevant in adult hippocampus as the higher brain region involved in the control of stress hormone levels in the body, as well as when considering the specific sensitivity of AHN to stress hormones concentration. Besides, we suggest a second further explanation for this profile specifically for adultborn neurons. It is tempting to speculate that an increasingly high number of newborn neurons in the adult hippocampus is not necessarily endlessly positive but much on the contrary, a very high number of newborn neurons can be detrimental for the functioning of the tri-synaptic hippocampal circuit. A too high number of newborn, immature neurons with specific and unique electrophysiological, morphological and connectivity properties into a fully mature circuit with mature granule neurons showing different physiological properties might cause an altered functioning of the system, after a very high intensity exercise. The evidences presented in this work may well be interpreted under the light of the proposed hypothesis, and as the adaptation of the system in response to very high intensity exercise to avoid the newborn neurons to accumulate beyond a given number, thereby the inverted- $U$ response curve.

\section{MECHANISMS OF BIPHASIC RESPONSES OF ADULT HIPPOCAMPAL NEUROGENESIS TO EXERCISE}

As a second part of our hypothesis and taking into account the mentioned literature, we also propose that the growth factors (IGF1 and BDNF among the main key factors) mediating actions of exercise on $\mathrm{AHN}$, may be potential candidates to mediate this response curve. Apart from GRs, some other molecular mediators of exercise actions on AHN have also been described displaying a hormetic-like dose-response for distinct parameters on brain, other than neurogenesis, thereby being putative candidates for the mediation of biphasic responses of neurogenesis. IGF1 has been reported as one of these factors, as a few exercise bouts induce no changes or even decrease serum levels (Kraemer et al., 1995), while long-term training increases IGF1 levels above pretraining values (Eliakim et al., 2006). IGF1 is able to induce neuronal rescue at low doses while no or opposite effects can be elicited at higher doses both in vivo (Johnston et al., 1996) and in vitro (Florini et al., 1986). No clear evidences exist about the mechanisms underlying this biphasic effect of IGF1 on brain, but a plausible suggestion is the well-known biphasic effect of insulin-like growth factor binding proteins, which are modulating the availability of IGFs for the canonical IGF receptors. In the choroid plexus, IGFBP2 enhances IGF1 biological actions at low levels while decrease the actions at higher concentrations (Delhanty and Han, 1993). These biphasic actions of IGF1 are also found in other organs like kidney (Wang et al., 2012), or muscle (Florini et al., 1986).

In the same way, secretion of VEGF in retinal epithelial cells to regulate cell proliferation displays a hormetic-like curve to hydroxynonenal in response to oxidative stress (Vatsyayan et al., 2012).

Finally but nevertheless, reactive oxygen species (ROS) can probably be mediators for hormesis in the responses to exercise (Radak et al., 2005; Goto and Radák, 2010). As explained before, ROS are compounds necessarily generated as a consequence of physical activity, in a dose-dependent manner. Oxidative stress is a basic, crucial response to the "alteration of redox homeostasis" generated by exercise (Nikolaidis et al., 2012). Depending on their concentration, their actions can be beneficial (as regulatory mediators in signaling processes or maintaining redox homeostasis) or detrimental for all major cellular components (Dröge, 2002). The stimulatory effects of low doses of ROS after moderate, intermittent stress, and the negative effects of high ROS dose after higher intensity exercise display a typical Ushaped dose-response curve. This hormetic profile is a major feature of adaptive stress responses, the underlying concept being that intermittent, moderate challenges increase the resistance of many different organ systems to chronic or higher levels of stress, and exercise-generated ROS, although inducing lipids, proteins and DNA oxidative damage, also induce the activation of redox sensitive transcription factors and signaling pathways necessary for the adaptive response (reviewed in Radak et al., 2008; Mattson, 2014).

\section{OTHER FACTORS INFLUENCING THE EFFECT OF EXERCISE}

Of course, other factors are involved in the body's response to exercise: the ergometer used, voluntary versus forced exercise, and the test used to analyze the behavior after the exercise protocol, among others. Very contradictory results have been reported when voluntary versus forced exercise are compared. Some works have reported an increase in locomotion after a voluntary running wheel while forced treadmill induced a decrease, together with the same opposite effect of these protocols on the number of GABAA receptors in striatum (Dishman et al., 1996). In the same line, other work reported an anxiogenic effect after forced treadmill exercise while voluntary exercise induced no effect (Leasure and Jones, 2008). Both works suggest an anxiogenic effect of forced but not voluntary exercise. Interestingly, in the latter work the authors observed the anxiogenic effect independently of the distance the animals ran, that was the same in both the voluntary wheel and the treadmill, and being the critical factor the speed of the exercise, consistenty higher in voluntary runners; this way the 
exercise took shorter time for voluntary runners in a daily basis. In parallel, AHN was significantly increased in both groups, voluntary and forced, being this increase higher in forced runners. This discrepancy between behavior and neurogenesis outcomes is in contradiction to most of the literature. It is relevant to take into account that both works used the open field alone to report locomotion or anxiety-like behaviors, and no other test to support the conclusions (elevated plus maze, or novelty suppressed feeding to mention just a few). On the contrary, other work has reported an anxiogenic effect of only voluntary wheel running compared to forced treadmill, by measuring contextual fear conditioning together with an increase in c-fos neuronal activation in amygdala (Burghardt et al., 2006).

All these studies and many others also point out to the duration of the daily exercise protocol and the duration of the whole exercise program (weeks or months) as another very relevant parameter for the different outcomes observed. Interestingly, the larger effects have been reported for the shorter durations of exercise protocols, concomitantly with the social isolation status of the animals (Hatchard et al., 2014). Motivation to run of the laboratory rodents used in the different studies, and the type of behavioral task used to test the animal conduct after the distinct exercise regimes are clearly determinant, key factors. Different tasks may require very different levels of motivation, and more relevantly, can recruit the activation of very distinct neural circuits and brain areas (see a review in García-Capdevila et al., 2009); brain region specific adaptations to exercise has also been recently reviewed (Morgan et al., 2015). Finally, to adequately compare works of voluntary versus forced exercise, different intensity levels, or human versus animal studies, measurement of $\mathrm{VO}_{2}$ and $\mathrm{VO}_{2 \max }$ would greatly improve our ability to analyze different results and to distinguish confounding variables.

\section{FINAL REMARKS}

As for many other factors/drugs/interventions with hormeticlike biphasic dose-response curves, hormetic responses to exercise can be highly relevant to take into account. For example, it is well-known that forced treadmill exercise can induce detrimental effects when performed after a deep brain surgery (Jun et al., 2012). In our hands, physical exercise on a treadmill after a surgical intervention of adult male mice modifies the

\section{REFERENCES}

Adlard, P. A., Perreau, V. M., Pop, V., and Cotman, C. W. (2005). Voluntary exercise decreases amyloid load in a transgenic model of Alzheimer's disease. J. Neurosci. 25, 4217-4221. doi: 10.1523/JNEUROSCI.0496-05.2005

Aguiar, A., Boemer, G., Rial, D., Cordova, F., Mancini, G., Walz, R., et al. (2010). High-intensity physical exercise disrupts implicit memory in mice: involvement of the striatal glutathione antioxidant system and intracellular signaling. Neuroscience 171, 1216-1227. doi: 10.1016/j.neuroscience.2010.09.053

Aguiar, A. S. Jr., Tuon, T., Pinho, C. A., Silva, L. A., Andreazza, A. C., Kapczinski, F., et al. (2008). Intense exercise induces mitochondrial dysfunction in mice brain. Neurochem. Res. 33, 51-58. doi: 10.1007/s11064-007-9406-x response both in hippocampus-dependent behaviors and in adult neurogenesis, by which the exercise intensity level usually promoting positive changes in neuron morphology, anxiolytic, and procognitive effects, induces after surgery no changes or changes in the opposite direction (forthcoming results). These findings can be easily interpreted in the way that surgery is diminishing the maximum positive response to exercise, and shortening the hormetic zone of exercise biphasic effects (Calabrese, 2008, all of them typical hormetic parameters). In the same line, some authors have recently reported that intensity level of exercise must be shifted down after a previous stress has been experienced, to obtain the usual positive effects typically measured by a variety of physiological parameters (Kim et al., 2015).

\section{CONCLUSIONS}

Some works have provided evidences that AHN might display hormetic-like biphasic dose-responses to exercise. A number of reports have also provided evidences that molecular mediators of exercise actions on neurogenesis, also respond with biphasic curves independently of their participation in the exerciseinduced effects on AHN. Taking into account both groups of evidences, we propose the hypothesis that adult neurogenesis might be a physical substrate for hormetic responses to exercise on cognition and mood, and that the growth factors (IGF1 and BDNF among the main key factors) mediating actions of exercise on $\mathrm{AHN}$, may be potential candidates to mediate this response curve, together with ROS.

\section{AUTHOR CONTRIBUTIONS}

SG, AP, KM, ÁF contributed to analyze the literature, made the Tables, and revise and made corrections to the draft of the manuscript. JT conceived the scientific main question, analyze the literature, wrote the draft and the final version of the manuscript, and is the correspondence author.

\section{ACKNOWLEDGMENTS}

The authors acknowledge the support of CSIC (Spanish Council for Scientific Investigation) and the Ministerio de Economía y Competitividad, Spain (research grant reference BFU201348907-R).

Andersen, K., Farahmand, B., Ahlbom, A., Held, C., Ljunghall, S., Michaëlsson, K., et al. (2013). Risk of arrhythmias in 52755 long-distance cross-country skiers: a cohort study. Eur. Heart J. 34, 3624-3631. doi: 10.1093/eurheartj/eht188

Ang, E., and Gomez-Pinilla, F. (2007). Potential therapeutic effects of exercise to the brain. Curr. Med. Chem. 14, 2564-2571. doi: 10.2174/0929867077820 23280

Baruch, D. E., Swain, R. A., and Helmstetter, F. J. (2004). Effects of exercise on Pavlovian fear conditioning. Behav. Neurosci. 118:1123. doi: 10.1037/07357044.118.5.1123

Bayod, S., Menella, I., Sanchez-Roige, S., Lalanza, J., Escorihuela, R., Camins, A., et al. (2014). Wnt pathway regulation by long-term moderate exercise in rat hippocampus. Brain Res. 1543, 38-48. doi: 10.1016/j.brainres.2013.10.048 
Bekinschtein, P., Oomen, C. A., Saksida, L. M., and Bussey, T. J. (2011). Effects of environmental enrichment and voluntary exercise on neurogenesis, learning and memory, and pattern separation: BDNF as a critical variable? Semin. Cell Dev. Biol. 22, 536-542. doi: 10.1016/j.semcdb.2011.07.002

Beneke, R., Hütler, M., and Leithauser, R. M. (2000). Maximal lactate-steadystate independent of performance. Med. Sci. Sports Exerc. 32, 1135-1139. doi: 10.1097/00005768-200006000-00016

Berchtold, N. C., Castello, N., and Cotman, C. W. (2010). Exercise and timedependent benefits to learning and memory. Neuroscience 167, 588-597. doi: 10.1016/j.neuroscience.2010.02.050

Billat, V. L., Mouisel, E., Roblot, N., and Melki, J. (2005). Inter- and intrastrain variation in mouse critical running speed. J. Appl. Physiol. (1985) 98, 1258-1263. doi: 10.1152/japplphysiol.00991.2004

Bjørnebekk, A., Mathé, A. A., and Brené, S. (2005). The antidepressant effect of running is associated with increased hippocampal cell proliferation. Int. J. Neuro Psychopharmacol. 8, 357-368. doi: 10.1017/s1461145705005122

Blustein, J. E., McLaughlin, M., and Hoffman, J. R. (2006). Exercise effects stressinduced analgesia and spatial learning in rats. Physiol. Behav. 89, 582-586. doi: 10.1016/j.physbeh.2006.07.017

Braszko, J. J., Kamiñski, K. A., Hryszko, T., Jedynak, W., and Brzósko, S. (2001). Diverse effects of prolonged physical training on learning of the delayed nonmatching to sample by rats. Neurosci. Res. 39, 79-84. doi: 10.1016/S0168-0102 (00)00207-8

Brown, J., Cooper-Kuhn, C. M., Kempermann, G., Van Praag, H., Winkler, J., Gage, F. H., et al. (2003). Enriched environment and physical activity stimulate hippocampal but not olfactory bulb neurogenesis. Eur. J. Neurosci. 17, 2042-2046. doi: 10.1046/j.1460-9568.2003.02647.x

Burghardt, P. R., Pasumarthi, R. K., Wilson, M. A., and Fadel, J. (2006). Alterations in fear conditioning and amygdalar activation following chronic wheel running in rats. Pharmacol. Biochem. Behav. 84, 306-312. doi: 10.1016/j.pbb.2006.05.015

Calabrese, E. J. (2008). Hormesis and medicine. Br. J. Clin. Pharmacol. 66, 594-617. doi: 10.1111/j.1365-2125.2008.03243.x

Calabrese, E. J., Bachmann, K. A., Bailer, A. J., Bolger, P. M., Borak, J., Cai, L., et al. (2007). Biological stress response terminology: integrating the concepts of adaptive response and preconditioning stress within a hormetic dose-response framework. Toxicol. Appl. Pharmacol. 222, 122-128. doi: 10.1016/j.taap.2007. 02.015

Calabrese, V., Cornelius, C., Mancuso, C., Lentile, R., Stella, A. M., and Butterfield, D. A. (2010). Redox homeostasis and cellular stress response in aging and neurodegeneration. Methods Mol. Biol. 610, 285-308. doi: 10.1007/978-160327-029-8_17

Cameron, H., Tanapat, P., and Gould, E. (1997). Adrenal steroids and N-methyl$\mathrm{D}$-aspartate receptor activation regulate neurogenesis in the dentate gyrus of adult rats through a common pathway. Neuroscience 82, 349-354. doi: 10.1016/S0306-4522(97)00303-5

Chae, C. H., Jung, S. L., An, S. H., Park, B. Y., Kim, T. W., Wang, S. W., et al. (2014). Swimming exercise stimulates neuro-genesis in the subventricular zone via increase in synapsin I and nerve growth factor levels. Biol. Sport 31, 309-314. doi: $10.5604 / 20831862.1132130$

Chen, C., and Tonegawa, S. (1997). Molecular genetic analysis of synaptic plasticity, activity-dependent neural development, learning, and memory in the mammalian brain. Annu. Rev. Neurosci. 20, 157-184. doi: 10.1146/annurev.neuro.20.1.157

Chen, H.-I., Lin, L.-C., Yu, L., Liu, Y.-F., Kuo, Y.-M., Huang, A.-M., et al. (2008). Treadmill exercise enhances passive avoidance learning in rats: the role of down-regulated serotonin system in the limbic system. Neurobiol. Learn. Mem. 89, 489-496. doi: 10.1016/j.nlm.2007.08.004

Chen, J., Zhang, Z. G., Li, Y., Wang, Y., Wang, L., Jiang, H., et al. (2003). Statins induce angiogenesis, neurogenesis, and synaptogenesis after stroke. Ann. Neurol. 53, 743-751. doi: 10.1002/ana.10555

Chen, M., and Do, H. (2012). Wnt signaling in neurogenesis during aging and physical activity. Brain Sci. 2, 745-768. doi: 10.3390/brainsci2040745

Cian, C., Barraud, P. A., Melin, B., and Raphel, C. (2001). Effects of fluid ingestion on cognitive function after heat stress or exercise-induced dehydration. Int. J. Psychophysiol. 42, 243-251. doi: 10.1016/S0167-8760(01)00142-8

Cotman, C. W., and Berchtold, N. C. (2002). Exercise: a behavioral intervention to enhance brain health and plasticity. Trends Neurosci. 25, 295-301. doi: 10.1016/S0166-2236(02)02143-4
Cotman, C. W., Berchtold, N. C., and Christie, L.-A. (2007). Exercise builds brain health: key roles of growth factor cascades and inflammation. Trends Neurosci. 30, 464-472. doi: 10.1016/j.tins.2007.06.011

Coyle, E. F. (2000). Physical activity as a metabolic stressor. Am. J. Clin. Nutr. 72, 512s-520s.

Creer, D. J., Romberg, C., Saksida, L. M., van Praag, H., and Bussey, T. J. (2010). Running enhances spatial pattern separation in mice. Proc. Natl. Acad. Sci. U.S.A. 107, 2367-2372. doi: 10.1073/pnas.0911725107

Delhanty, P., and Han, V. (1993). The expression of insulin-like growth factor (IGF)-binding protein-2 and IGF-II genes in the tissues of the developing ovine fetus. Endocrinology 132, 41-52.

Dietrich, M. O., and Horvath, T. L. (2012). Limitations in anti-obesity drug development: the critical role of hunger-promoting neurons. Nat. Rev. Drug Discov. 11, 675-691. doi: 10.1038/nrd3739

Ding, Q., Vaynman, S., Akhavan, M., Ying, Z., and Gomez-Pinilla, F. (2006). Insulin-like growth factor I interfaces with brain-derived neurotrophic factormediated synaptic plasticity to modulate aspects of exercise-induced cognitive function. Neuroscience 140, 823-833. doi: 10.1016/j.neuroscience.2006. 02.084

Dishman, R. K., Berthoud, H. R., Booth, F. W., Cotman, C. W., Edgerton, V. R., Fleshner, M. R., et al. (2006). Neurobiology of exercise. Obesity (Silver Spring) 14, 345-356. doi: 10.1038/oby.2006.46

Dishman, R. K., Dunn, A. L., Youngstedt, S. D., Davis, J. M., Burgess, M. L., Wilson, S. P., et al. (1996). Increased open field locomotion and decreased striatal GABA A binding after activity wheel running. Physiol. Behav. 60, 699-705. doi: 10.1016/0031-9384(96)00102-3

Dröge, W. (2002). Free radicals in the physiological control of cell function. Physiol. Rev. 82, 47-95. doi: 10.1152/physrev.00018.2001

During, M. J., and Cao, L. (2006). VEGF, a mediator of the effect of experience on hippocampal neurogenesis. Curr. Alzheimer Res. 3, 29-33. doi: $10.2174 / 156720506775697133$

Eadie, B. D., Redila, V. A., and Christie, B. R. (2005). Voluntary exercise alters the cytoarchitecture of the adult dentate gyrus by increasing cellular proliferation, dendritic complexity, and spine density. J. Comp. Neurol. 486, 39-47. doi: $10.1002 / \mathrm{cne} .20493$

Eliakim, A., Nemet, D., Zaldivar, F., McMurray, R. G., Culler, F. L., Galassetti, P., et al. (2006). Reduced exercise-associated response of the GH-IGF-I axis and catecholamines in obese children and adolescents. J. Appl. Physiol. 100, 1630-1637. doi: 10.1152/japplphysiol.01072.2005

Fabel, K., Fabel, K., Tam, B., Kaufer, D., Baiker, A., Simmons, N., et al. (2003). VEGF is necessary for exercise-induced adult hippocampal neurogenesis. Eur. J. Neurosci. 18, 2803-2812. doi: 10.1111/j.1460-9568.2003.03041.x

Falls, W. A., Fox, J. H., and MacAulay, C. M. (2010). Voluntary exercise improves both learning and consolidation of cued conditioned fear in C57 mice. Behav. Brain Res. 207, 321-331. doi: 10.1016/j.bbr.2009.10.016

Ferreira, J. C., Rolim, N. P., Bartholomeu, J. B., Gobatto, C. A., Kokubun, E., and Brum, P. C. (2007). Maximal lactate steady state in running mice: effect of exercise training. Clin. Exp. Pharmacol. Physiol. 34, 760-765. doi: 10.1111/j.1440-1681.2007.04635.x

Fischer, T. J., Walker, T. L., Overall, R. W., Brandt, M. D., and Kempermann, G. (2014). Acute effects of wheel running on adult hippocampal precursor cells in mice are not caused by changes in cell cycle length or $\mathrm{S}$ phase length. Front. Neurosci. 8:314. doi: 10.3389/fnins.2014.00314

Florini, J. R., Ewton, D. Z., Falen, S. L., and Van Wyk, J. J. (1986). Biphasic concentration dependency of stimulation of myoblast differentiation by somatomedins. Am. J. Physiol. Cell Physiol. 250, C771-C778.

Foster, P. P. (2015). Role of physical and mental training in brain network configuration. Front. Aging Neurosci. 7:117. doi: 10.3389/fnagi.2015.00117

García-Capdevila, S., Portell-Cortés, I., Torras-Garcia, M., Coll-Andreu, M., and Costa-Miserachs, D. (2009). Effects of long-term voluntary exercise on learning and memory processes: dependency of the task and level of exercise. Behav. Brain Res. 202, 162-170. doi: 10.1016/j.bbr.2009.03.020

Garcia-Segura, L. M. (2009). Hormones and Brain Plasticity. New York, NY: Oxford University Press.

Glasper, E. R., Llorens-Martin, M. V., Leuner, B., Gould, E., and Trejo, J. L. (2010). Blockade of insulin-like growth factor-I has complex effects on structural plasticity in the hippocampus. Hippocampus 20, 706-712. doi: 10.1002/hipo.20672 
Gobatto, C. A., de Mello, M. A., Sibuya, C. Y., de Azevedo, J. R., dos, Santos, L. A., and Kokubun, E. (2001). Maximal lactate steady state in rats submitted to swimming exercise. Comp. Biochem. Physiol. A Mol. Integr. Physiol. 130, 21-27. doi: 10.1016/S1095-6433(01)00362-2

Gomez-Pinilla, F. (2008). The influences of diet and exercise on mental health through hormesis. Ageing Res. Rev. 7, 49-62. doi: 10.1016/j.arr.2007.04.003

Gomez-Pinilla, F., and Hillman, C. (2013). The influence of exercise on cognitive abilities. Compr. Physiol. 3, 403-428. doi: 10.1002/cphy.c110063

Goto, S., and Radák, Z. (2010). Hormetic effects of reactive oxygen species by exercise: a view from animal studies for successful aging in human. Dose Resp. 8, 68-72. doi: 10.2203/dose-response.09-044.Goto

Gould, E., and Tanapat, P. (1999). Stress and hippocampal neurogenesis. Biol. Psychiatry 46, 1472-1479. doi: 10.1016/S0006-3223(99)00247-4

Grebot, C., Groslambert, A., Pernin, J.-N., Burtheret, A., and Rouillon, J.-D. (2003). Effects of exercise on perceptual estimation and short-term recall of shooting performance in a biathlon. Percept. Mot. Skills 97, 1107-1114. doi: 10.2466/PMS.97.8.1107-1114

Griesbach, G. S., Gomez-Pinilla, F., and Hovda, D. A. (2004). The upregulation of plasticity-related proteins following TBI is disrupted with acute voluntary exercise. Brain Res. 1016, 154-162. doi: 10.1016/j.brainres.2004.04.079

Griffin, E. W., Bechara, R. G., Birch, A. M., and Kelly, A. M. (2009). Exercise enhances hippocampal-dependent learning in the rat: evidence for a BDNFrelated mechanism. Hippocampus 19, 973-980. doi: 10.1002/hipo.20631

Guilloux, J.-P., Mendez-David, I., Pehrson, A., Guiard, B. P., Repérant, C., Orvoën, S., et al. (2013). Antidepressant and anxiolytic potential of the multimodal antidepressant vortioxetine (Lu AA21004) assessed by behavioural and neurogenesis outcomes in mice. Neuropharmacology 73, 147-159. doi: 10.1016/j.neuropharm.2013.05.014

Gwag, B. J., Koh, J. Y., Chen, M. M., Dugan, L. L., Behrens, M. M., Lobner, D., et al. (1995). BDNF or IGF-I potentiates free radical-mediated injury in cortical cell cultures. Neuroreport 7, 93-96. doi: 10.1097/00001756-199512000-00022

Hagedorn, L., Floris, J., Suter, U., and Sommer, L. (2000). Autonomic neurogenesis and apoptosis are alternative fates of progenitor cell communities induced by TGFß. Dev. Biol. 228, 57-72. doi: 10.1006/dbio.2000.9936

Hardy, C. J., and Rejeski, W. J. (1989). Not what, but how one feels: the measurement of affect during exercise. J. Sport Exerc. Psychol. 11, 304-317.

Hatchard, T., Ting, J. J., and Messier, C. (2014). Translating the impact of exercise on cognition: methodological issues in animal research. Behav. Brain Res. 273, 177-188. doi: 10.1016/j.bbr.2014.06.043

Hillman, C. H., Erickson, K. I., and Kramer, A. F. (2008). Be smart, exercise your heart: exercise effects on brain and cognition. Nat. Rev. Neurosci. 9, 58-65. doi: $10.1038 / \mathrm{nrn} 2298$

Holmes, M. M., Galea, L. A., Mistlberger, R. E., and Kempermann, G. (2004). Adult hippocampal neurogenesis and voluntary running activity: circadian and dose-dependent effects. J. Neurosci. Res. 76, 216-222. doi: 10.1002/jnr.20039

Hornsby, A. K., Redhead, Y. T., Rees, D. J., Ratcliff, M. S., Reichenbach, A., Wells, T., et al. (2016). Short-term calorie restriction enhances adult hippocampal neurogenesis and remote fear memory in a Ghsr-dependent manner. Psychoneuroendocrinology 63, 198-207. doi: 10.1016/j.psyneuen.2015. 09.023

Inoue, K., Hanaoka, Y., Nishijima, T., Okamoto, M., Chang, H., Saito, T., et al. (2015a). Long-term mild exercise training enhances hippocampus-dependent memory in rats. Int. J. Sports Med. 36, 280-285. doi: 10.1055/s-0034-1390465

Inoue, K., Okamoto, M., Shibato, J., Lee, M. C., Matsui, T., Rakwal, R., et al. (2015b). Long-term mild, rather than intense, exercise enhances adult hippocampal neurogenesis and greatly changes the transcriptomic profile of the hippocampus. PLOS ONE 10:e0128720. doi: 10.1371/journal.pone.0128720

Joëls, M. (2006). Corticosteroid effects in the brain: U-shape it. Trends Pharmacol. Sci. 27, 244-250. doi: 10.1016/j.tips.2006.03.007

Johnston, B. M., Mallard, E. C., Williams, C. E., and Gluckman, P. D. (1996). Insulin-like growth factor- 1 is a potent neuronal rescue agent after hypoxicischemic injury in fetal lambs. J. Clin. Invest. 97, 300. doi: 10.1172/JCI 118416

Jun, H., Mohammed Qasim Hussaini, S., Rigby, M. J., and Jang, M. H. (2012). Functional role of adult hippocampal neurogenesis as a therapeutic strategy for mental disorders. Neural Plast. 2012, 854285. doi: 10.1155/2012/854285

Kempermann, G. (2011). Adult Neurogenesis 2. New York, NY: Oxford University Press.
Kempermann, G., van Praag, H., and Gage, F. H. (1999). Activity-dependent regulation of neuronal plasticity and self repair. Prog. Brain Res. 127, 35-48. doi: 10.1016/S0079-6123(00)27004-0

Kennard, J. A., and Woodruff-Pak, D. S. (2012). A comparison of lowand high-impact forced exercise: effects of training paradigm on learning and memory. Physiol. Behav. 106, 423-427. doi: 10.1016/j.physbeh.2012. 02.023

Kim, M. E., Park, H. R., Gong, E. J., Choi, S. Y., Kim, H. S., and Lee, J. (2011). Exposure to bisphenol A appears to impair hippocampal neurogenesis and spatial learning and memory. Food Chem. Toxicol. 49, 3383-3389. doi: 10.1016/j.fct.2011.09.017

Kim, T.-K., Park, J.-Y., and Han, P.-L. (2015). Physiological parameters in the blood of a murine stress-induced depression model before and after repeated passive exercise. Endocrinol. Metab. (Seoul). 30, 371-380. doi: 10.3803/enm. 2015.30.3.371

Kohl, Z., Kandasamy, M., Winner, B., Aigner, R., Gross, C., Couillard-Despres, S., et al. (2007). Physical activity fails to rescue hippocampal neurogenesis deficits in the R6/2 mouse model of Huntington's disease. Brain Res. 1155, 24-33. doi: 10.1016/j.brainres.2007.04.039

Kraemer, W. J., Aguilera, B. A., Terada, M., Newton, R. U., Lynch, J. M., Rosendaal, G., et al. (1995). Responses of IGF-I to endogenous increases in growth hormone after heavy-resistance exercise. J. Appl. Physiol. 79, 1310-1315.

Kramer, A. F., Erickson, K. I., and Colcombe, S. J. (2006). Exercise, cognition, and the aging brain. J. Appl. Physiol. 101, 1237-1242. doi: 10.1152/japplphysiol.00500.2006

Kronenberg, G., Bick-Sander, A., Bunk, E., Wolf, C., Ehninger, D., and Kempermann, G. (2006). Physical exercise prevents age-related decline in precursor cell activity in the mouse dentate gyrus. Neurobiol. Aging 27, 1505-1513. doi: 10.1016/j.neurobiolaging.2005.09.016

Lafenêtre, P., Leske, O., Ma-Högemeie, Z., Haghikia, A., Bichler, Z., Wahle, P., et al. (2010). Exercise can rescue recognition memory impairment in a model with reduced adult hippocampal neurogenesis. Front. Behav. Neurosci. 3:34. doi: 10.3389 /neuro.08.034.2009

Leasure, J., and Jones, M. (2008). Forced and voluntary exercise differentially affect brain and behavior. Neuroscience 156, 456-465. doi: 10.1016/j.neuroscience.2008.07.041

Leasure, J. L., and Decker, L. (2009). Social isolation prevents exercise-induced proliferation of hippocampal progenitor cells in female rats. Hippocampus 19, 907-912. doi: 10.1002/hipo.20563

Lee, I. M., Hsieh, C. C., and Paffenbarger, R. S. Jr. (1995). Exercise intensity and longevity in men. The Harvard Alumni Health Study. JAMA 273, 1179-1184. doi: 10.1001/jama.1995.03520390039030

Leuner, B., Caponiti, J. M., and Gould, E. (2012). Oxytocin stimulates adult neurogenesis even under conditions of stress and elevated glucocorticoids. Hippocampus 22, 861-868. doi: 10.1002/hipo.20947

Lezi, E., Burns, J. M., and Swerdlow, R. H. (2014). Effect of high-intensity exercise on aged mouse brain mitochondria, neurogenesis, and inflammation. Neurobiol. Aging 35, 2574-2583. doi: 10.1016/j.neurobiolaging.2014 05.033

Li, H., Liang, A., Guan, F., Fan, R., Chi, L., and Yang, B. (2013). Regular treadmill running improves spatial learning and memory performance in young mice through increased hippocampal neurogenesis and decreased stress. Brain Res. 1531, 1-8. doi: 10.1016/j.brainres.2013.07.041

Lin, T.-W., Chen, S.-J., Huang, T.-Y., Chang, C.-Y., Chuang, J.-I., Wu, F.-S., et al. (2012). Different types of exercise induce differential effects on neuronal adaptations and memory performance. Neurobiol. Learn. Mem. 97, 140-147. doi: 10.1016/j.nlm.2011.10.006

Liu, J. W., Tian, S. J., de Barry, J., and Luu, B. (2007). Panaxadiol glycosides that induce neuronal differentiation in neurosphere stem cells. J. Nat. Prod. 70, 1329-1334. doi: 10.1021/np070135j

Liu, Y.-F., Chen, H.-I., Yu, L., Kuo, Y.-M., Wu, F.-S., Chuang, J.-I., et al. (2008) Upregulation of hippocampal TrkB and synaptotagmin is involved in treadmill exercise-enhanced aversive memory in mice. Neurobiol. Learn. Mem. 90, 81-89. doi: 10.1016/j.nlm.2008.02.005

Llorens-Martín, M., Torres-Alemán, I., and Trejo, J. L. (2006). Pronounced individual variation in the response to the stimulatory action of exercise on immature hippocampal neurons. Hippocampus 16, 480-490. doi: 10.1002/hipo. 20175 
Llorens-Martin, M., Torres-Alemán, I., and Trejo, J. L. (2008). Growth factors as mediators of exercise actions on the brain. Neuromol. Med. 10, 99-107. doi: 10.1007/s12017-008-8026-1

Lou, S.-J., Liu, J.-Y., Chang, H., and Chen, P.-J. (2008). Hippocampal neurogenesis and gene expression depend on exercise intensity in juvenile rats. Brain Res. 1210, 48-55. doi: 10.1016/j.brainres.2008.02.080

Lucas, S. J., Cotter, J. D., Brassard, P., and Bailey, D. M. (2015). High-intensity interval exercise and cerebrovascular health: curiosity, cause, and consequence. J. Cereb. Blood Flow Metab. 35, 902-911. doi: 10.1038/jcbfm.2015.49

Marosi, K., and Mattson, M. P. (2014). BDNF mediates adaptive brain and body responses to energetic challenges. Trends Endocrinol. Metab. 25, 89-98. doi: 10.1016/j.tem.2013.10.006

Llorens-Martin, M., Torres-Aleman, I., and Trejo, J. L. (2009). Reviews: mechanisms mediating brain plasticity: IGF1 and adult hippocampal neurogenesis. Neuroscientist 15, 134-148. doi: 10.1177/1073858408331371

LLorens-Martín, M., Torres-Alemán, I., and Trejo, J. L. (2010). Exercise modulates insulin-like growth factor 1-dependent and-independent effects on adult hippocampal neurogenesis and behaviour. Mol. Cell. Neurosci. 44, 109-117. doi: 10.1016/j.mcn.2010.02.006

Mattson, M. P. (2000). Neuroprotective signaling and the aging brain: take away my food and let me run. Brain Res. 886, 47-53. doi: 10.1016/S00068993(00)02790-6

Mattson, M. P. (2008). Hormesis defined. Ageing Res. Rev. 7, 1-7. doi: 10.1016/j.arr.2007.08.007

Mattson, M. P. (2012a). Energy intake and exercise as determinants of brain health and vulnerability to injury and disease. Cell Metab. 16, 706-722. doi: 10.1016/j.cmet.2012.08.012

Mattson, M. P. (2012b). Evolutionary aspects of human exercise-born to run purposefully. Ageing Res. Rev. 11, 347-352. doi: 10.1016/j.arr.2012.01.007

Mattson, M. P. (2014). Challenging oneself intermittently to improve health. Dose Res. 12, 600-618. doi: 10.2203/dose-response.14-028.Mattson

Mattson, M. P. (2015). Lifelong brain health is a lifelong challenge: from evolutionary principles to empirical evidence. Ageing Res. Rev. 20, 37-45. doi: 10.1016/j.arr.2014.12.011

Mattson, M. P., Duan, W., Wan, R., and Guo, Z. (2004). Prophylactic activation of neuroprotective stress response pathways by dietary and behavioral manipulations. NeuroRx 1, 111-116. doi: 10.1602/neurorx.1.1.111

Mattson, M. P., Son, T. G., and Camandola, S. (2007). Viewpoint: mechanisms of action and therapeutic potential of neurohormetic phytochemicals. Dose Res. 5 , 174-186. doi: 10.2203/dose-response.07-004.Mattson

McEwen, B. S. (2012). The ever-changing brain: cellular and molecular mechanisms for the effects of stressful experiences. Dev. Neurobiol. 72, 878-890. doi: 10.1002/dneu.20968

Meeusen, R. F. V. (2012). "The monoaminergic system in animal models of exercise," in Functional Neuroimaging in Exercise and Sport Sciences, eds H. H. Boecker, C. H. Hillman, L. Scheef, and H. K. Strüder (New York, NY: Springer), 59-76.

Meng, H., Zhang, Z., Zhang, R., Liu, X., Wang, L., Robin, A. M., et al. (2006). Biphasic effects of exogenous VEGF on VEGF expression of adult neural progenitors. Neurosci. Lett. 393, 97-101. doi: 10.1016/j.neulet.2005.09.044

Morgan, J. A., Corrigan, F., and Baune, B. T. (2015). Effects of physical exercise on central nervous system functions: a review of brain region specific adaptations. J. Mol. Psychiatry 3, 3. doi: 10.1186/s40303-015-0010-8

Nam, S. M., Kim, J. W., Yoo, D. Y., Yim, H. S., Kim, D. W., Choi, J. H., et al. (2014). Physical exercise ameliorates the reduction of neural stem cell, cell proliferation and neuroblast differentiation in senescent mice induced by $\mathrm{D}$-galactose. $B M C$ Neurosci. 15:116. doi: 10.1186/s12868-014-0116-4

Naylor, A. S., Bull, C., Nilsson, M. K., Zhu, C., Björk-Eriksson, T., Eriksson, P. S., et al. (2008). Voluntary running rescues adult hippocampal neurogenesis after irradiation of the young mouse brain. Proc. Natl. Acad. Sci. U.S.A. 105, 14632-14637. doi: 10.1073/pnas.0711128105

Nieman, D. C., Johanssen, L. M., Lee, J., and Arabatzis, K. (1990). Infectious episodes in runners before and after the Los Angeles Marathon. J. Sports Med. Phys. Fitness 30, 316-328.

Nikolaidis, M. G., Kyparos, A., Spanou, C., Paschalis, V., Theodorou, A. A., and Vrabas, I. S. (2012). Redox biology of exercise: an integrative and comparative consideration of some overlooked issues. J. Exp. Biol. 215, 1615-1625. doi: 10.1242/jeb.067470
Ogonovszky, H., Berkes, I., Kumagai, S., Kaneko, T., Tahara, S., Goto, S., et al. (2005). The effects of moderate-, strenuous-and over-training on oxidative stress markers, DNA repair, and memory, in rat brain. Neurochem. Int. 46, 635-640. doi: 10.1016/j.neuint.2005.02.009

Okamoto, M., Yamamura, Y., Liu, Y.-F., Min-Chul, L., Matsui, T., Shima, T., et al. (2015). Hormetic effects by exercise on hippocampal neurogenesis with glucocorticoid signaling. Brain Plast. 1, 149-158. doi: 10.3233/BPL-150012

Oliveira, B. R., Deslandes, A. C., and Santos, T. M. (2015). Differences in exercise intensity seems to influence the affective responses in self-selected and imposed exercise: a meta-analysis. Front. Psychol. 6:1105. doi: 10.3389/fpsyg.2015.01105

Olson, A. K., Eadie, B. D., Ernst, C., and Christie, B. R. (2006). Environmental enrichment and voluntary exercise massively increase neurogenesis in the adult hippocampus via dissociable pathways. Hippocampus 16, 250-260. doi: 10.1002/hipo.20157

Opendak, M., and Gould, E. (2015). Adult neurogenesis: a substrate for experience-dependent change. Trends Cogn. Sci. 19, 151-161. doi: 10.1016/j.tics.2015.01.001

Peake, J. M., Markworth, J. F., Nosaka, K., Raastad, T., Wadley, G. D., and Coffey, V. G. (2015). Modulating exercise-induced hormesis: does less equal more? J. Appl. Physiol. 119, 172-189. doi: 10.1152/japplphysiol.01055.2014

Pérez-Domper, P., Gradari, S., and Trejo, J. L. (2013). The growth factors cascade and the dendrito-/synapto-genesis versus cell survival in adult hippocampal neurogenesis: the chicken or the egg. Ageing Res. Rev. 12, 777-785. doi: 10.1016/j.arr.2013.06.001

Powers, S. K., and Jackson, M. J. (2008). Exercise-induced oxidative stress: cellular mechanisms and impact on muscle force production. Physiol. Rev. 88, 1243-1276. doi: 10.1152/physrev.00031.2007

Radahmadi, M., Alaei, H., Sharifi, M. R., and Hosseini, N. (2015). Effect of forced exercise and exercise withdrawal on memory, serum and hippocampal corticosterone levels in rats. Exp. Brain Res. 233, 2789-2799. doi: 10.1007/s00221-015-4349-y

Radak, Z., Chung, H. Y., and Goto, S. (2005). Exercise and hormesis: oxidative stress-related adaptation for successful aging. Biogerontology 6, 71-75. doi: 10.1007/s10522-004-7386-7

Radak, Z., Chung, H. Y., Koltai, E., Taylor, A. W., and Goto, S. (2008). Exercise, oxidative stress and hormesis. Ageing Res. Rev. 7, 34-42. doi: 10.1016/j.arr.2007.04.004

Radak, Z., Ihasz, F., Koltai, E., Goto, S., Taylor, A. W., and Boldogh, I. (2014). The redox-associated adaptive response of brain to physical exercise. Free Radic. Res. 48, 84-92. doi: 10.3109/10715762.2013.826352

Radák, Z., Kaneko, T., Tahara, S., Nakamoto, H., Pucsok, J., Sasvári, M., et al. (2001). Regular exercise improves cognitive function and decreases oxidative damage in rat brain. Neurochem. Int. 38, 17-23. doi: 10.1016/S01970186(00)00063-2

Radak, Z., Toldy, A., Szabo, Z., Siamilis, S., Nyakas, C., Silye, G., et al. (2006). The effects of training and detraining on memory, neurotrophins and oxidative stress markers in rat brain. Neurochem. Int. 49, 387-392. doi: 10.1016/j.neuint.2006.02.004

Radak, Z., Zhao, Z., Koltai, E., Ohno, H., and Atalay, M. (2013). Oxygen consumption and usage during physical exercise: the balance between oxidative stress and ROS-dependent adaptive signaling. Antioxid. Redox Signal. 18, 1208-1246. doi: 10.1089/ars.2011.4498

Ramsden, M., Berchtold, N. C., Kesslak, J. P., Cotman, C. W., and Pike, C. J. (2003). Exercise increases the vulnerability of rat hippocampal neurons to kainate lesion. Brain Res. 971, 239-244. doi: 10.1016/S0006-8993(03)02365-5

Redila, V., and Christie, B. (2006). Exercise-induced changes in dendritic structure and complexity in the adult hippocampal dentate gyrus. Neuroscience 137, 1299-1307. doi: 10.1016/j.neuroscience.2005.10.050

Rhodes, J. S., Van Praag, H., Jeffrey, S., Girard, I., Mitchell, G. S., Garland T. Jr., et al. (2003). Exercise increases hippocampal neurogenesis to high levels but does not improve spatial learning in mice bred for increased voluntary wheel running. Behav. Neurosci. 117:1006. doi: 10.1037/0735-7044.117.5.1006

Rooks, C. R., Thom, N. J., McCully, K. K., and Dishman, R. K. (2010). Effects of incremental exercise on cerebral oxygenation measured by nearinfrared spectroscopy: a systematic review. Prog. Neurobiol. 92, 134-150. doi: 10.1016/j.pneurobio.2010.06.002

Rosa, E. F., Takahashi, S., Aboulafia, J., Nouailhetas, V. L., and Oliveira, M. G. (2007). Oxidative stress induced by intense and exhaustive exercise 
impairs murine cognitive function. J. Neurophysiol. 98, 1820-1826. doi: 10.1152/jn.01158.2006

Rothman, S., and Mattson, M. (2013). Activity-dependent, stress-responsive BDNF signaling and the quest for optimal brain health and resilience throughout the lifespan. Neuroscience 239, 228-240. doi: 10.1016/j.neuroscience.2012.10.014

Saaltink, D.-J., and Vreugdenhil, E. (2014). Stress, glucocorticoid receptors, and adult neurogenesis: a balance between excitation and inhibition? Cell. Mol. Life Sci. 71, 2499-2515. doi: 10.1007/s00018-014-1568-5

Samorajski, T., Delaney, C., Durham, L., Ordy, J., Johnson, J., and Dunlap, W. (1985). Effect of exercise on longevity, body weight, locomotor performance, and passive-avoidance memory of C57BL/6J mice. Neurobiol. Aging 6, 17-24. doi: 10.1016/0197-4580(85)90066-1

Sapolsky, R. M., Krey, L. C., and McEwen, B. S. (1986). The neuroendocrinology of stress and aging: the glucocorticoid cascade hypothesis*. Endocr. Rev. 7, 284-301. doi: 10.1210/edrv-7-3-284

Schoenfeld, T. J., and Gould, E. (2013). Differential effects of stress and glucocorticoids on adult neurogenesis. Curr. Top Behav. Neurosci. 15, 139-164. doi: 10.1007/7854_2012_233

Schweitzer, N. B., Alessio, H. M., Berry, S. D., Roeske, K., and Hagerman, A. E. (2006). Exercise-induced changes in cardiac gene expression and its relation to spatial maze performance. Neurochem. Int. 48, 9-16. doi: 10.1016/j.neuint.2005.08.006

Seo, T. B., Cho, H. S., Shin, M. S., Kim, C. J., Ji, E. S., and Baek, S. S. (2013). Treadmill exercise improves behavioral outcomes and spatial learning memory through up-regulation of reelin signaling pathway in autistic rats. J. Exerc. Rehabil. 9, 220-229. doi: 10.12965/jer.130003

Shen, X., Li, A., Zhang, Y., Dong, X., Shan, T., Wu, Y., et al. (2013). The effect of different intensities of treadmill exercise on cognitive function deficit following a severe controlled cortical impact in rats. Int. J. Mol. Sci. 14, 21598-21612. doi: 10.3390/ijms 141121598

Shih, P.-C., Yang, Y.-R., and Wang, R.-Y. (2013). Effects of exercise intensity on spatial memory performance and hippocampal synaptic plasticity in transient brain ischemic rats. PLOS ONE 8:e78163. doi: 10.1371/journal.pone.00 78163

Silverman, M. N., and Deuster, P. A. (2014). Biological mechanisms underlying the role of physical fitness in health and resilience. Interface Focus 4, 20140040. doi: 10.1098/rsfs.2014.0040

Soya, H., Mukai, A., Deocaris, C. C., Ohiwa, N., Chang, H., Nishijima, T., et al. (2007). Threshold-like pattern of neuronal activation in the hypothalamus during treadmill running: establishment of a minimum running stress (MRS) rat model. Neurosci. Res. 58, 341-348. doi: 10.1016/j.neures.2007. 04.004

Stranahan, A. M., Khalil, D., and Gould, E. (2007). Running induces widespread structural alterations in the hippocampus and entorhinal cortex. Hippocampus 17, 1017. doi: 10.1002/hipo.20348

Szuhany, K. L., Bugatti, M., and Otto, M. W. (2015). A meta-analytic review of the effects of exercise on brain-derived neurotrophic factor. J. Psychiatr. Res. 60, 56-64. doi: 10.1016/j.jpsychires.2014.10.003

Taverniers, J., Van Ruysseveldt, J., Smeets, T., and von Grumbkow, J. (2010). High-intensity stress elicits robust cortisol increases, and impairs working memory and visuo-spatial declarative memory in special forces candidates: a field experiment. Stress 13, 323-333. doi: 10.3109/102538910036 42394

Timofeeva, E., Huang, Q., and Richard, D. (2003). Effects of treadmill running on brain activation and the corticotropin-releasing hormone system. Neuroendocrinology 77, 388-405. doi: 10.1159/000071311

Tomporowski, P. D. (2003). Effects of acute bouts of exercise on cognition. Acta Psychol. (Amst) 112, 297-324. doi: 10.1016/S0001-6918(02)00134-8

Trejo, J. L., Carro, E., and Torres-Aleman, I. (2001). Circulating insulin-like growth factor I mediates exercise-induced increases in the number of new neurons in the adult hippocampus. J. Neurosci. 21, 1628-1634.

Trejo, J. L., Llorens-Martin, M., and Torres-Alemán, I. (2008). The effects of exercise on spatial learning and anxiety-like behavior are mediated by an IGF-I-dependent mechanism related to hippocampal neurogenesis. Mol. Cell. Neurosci. 37, 402-411. doi: 10.1016/j.mcn.2007.10.016

Van Praag, H., Christie, B. R., Sejnowski, T. J., and Gage, F. H. (1999). Running enhances neurogenesis, learning, and long-term potentiation in mice. Proc. Natl. Acad. Sci. U.S.A. 96, 13427-13431. doi: 10.1073/pnas.96.23.13427

Vatsyayan, R., Lelsani, P. C. R., Chaudhary, P., Kumar, S., Awasthi, S., and Awasthi, Y. C. (2012). The expression and function of vascular endothelial growth factor in retinal pigment epithelial (RPE) cells is regulated by 4-hydroxynonenal (HNE) and glutathione S-transferaseA4-4. Biochem. Biophys. Res. Commun. 417, 346-351. doi: 10.1016/j.bbrc.2011.11.113

Vivar, C., Potter, M. C., and van Praag, H. (2013). All about running: synaptic plasticity, growth factors and adult hippocampal neurogenesis. Curr. Top Behav. Neurosci. 15, 189-210. doi: 10.1007/7854_2012_220

Wang, G. (2013). Hormesis, cell death, and regenerative medicine for neurodegenerative diseases. Dose Response 11, 238-254. doi: 10.2203/doseresponse.12-019.Wang

Wang, J. M. (2014). Allopregnanolone and neurogenesis in the nigrostriatal tract. Front. Cell. Neurosci. 8:224. doi: 10.3389/fncel.2014.00224

Wang, L., Li, W., Kong, S., Wu, P., Zhang, C., Gu, L., et al. (2012). Insulinlike growth factor-1 (IGF-1) inhibits the basolateral $\mathrm{Cl}$ channels in the thick ascending limb of the rat kidney. Biochim. Biophys. Acta 1823, 1163-1169. doi: 10.1016/j.bbamcr.2012.04.015

White, L., Cory-Slechta, D., Gilbert, M., Tiffany-Castiglioni, E., Zawia, N., Virgolini, M., et al. (2007). New and evolving concepts in the neurotoxicology of lead. Toxicol. Appl. Pharmacol. 225, 1-27. doi: 10.1016/j.taap.2007.08.001

Conflict of Interest Statement: The authors declare that the research was conducted in the absence of any commercial or financial relationships that could be construed as a potential conflict of interest.

Copyright (c) 2016 Gradari, Pallé, McGreevy, Fontán-Lozano and Trejo. This is an open-access article distributed under the terms of the Creative Commons Attribution License (CC BY). The use, distribution or reproduction in other forums is permitted, provided the original author(s) or licensor are credited and that the original publication in this journal is cited, in accordance with accepted academic practice. No use, distribution or reproduction is permitted which does not comply with these terms. 